\title{
53-Year-old man with fever, malaise and dyspnoea
}

\author{
Nancy Lutwak, Curt Dill \\ Department of Emergency Medicine, VA New York Harbor Healthcare System, NYU School of Medicine, New York, USA \\ Correspondence to Dr Nancy Lutwak, nancy.lutwak@gmail.com
}

The patient is a 53-year-old man with 2 weeks of fever, sore throat, malaise, intermittent vomiting and diarrhoea. He had developed dyspnoea 2 days prior to presentation to the emergency department. He denied rashes, cough, abdominal pain, insect bites and chest pain.

The patient history is significant for coronary artery disease, hypertension, rheumatoid arthritis and hyperlipidaemia. The patient denied previous episodes of presyncope or syncope. Medications included amlodipine $5 \mathrm{mg}$ daily.

The patient had travelled to Connecticut within 1 week of developing the febrile illness.

Physical examination revealed temperature of $99.8(\mathrm{~F})$, blood pressure of 106/67 and heart rate of 50 . The remainder of the exam was negative. An electrocardiogram was performed (figure 1).

Despite the patient's recent travel to Connecticut, in the view of the infectious disease consultant, the suspicion for Lyme disease was low. The patient had no headaches, arthralgias, rash or history of tick bites. Western blot immunoglobulin $\mathrm{M}(\operatorname{IgM})$ and $\operatorname{IgG}$ titres were sent immediately after admission, but the patient was not treated with ceftriaxone for Lyme disease because of the opinion of the consulting physician. Prior to the availability of the results which were positive, the patient needed a temporary pacemaker after developing junctional escape at 35. A dual chamber permanent pacemaker was then placed with the assumption that the patient did not have Lyme disease. This intervention may have been avoided if the antibiotic had been started immediately. In addition, there was a 4-week delay in treatment with antibiotics since the patient was discharged from the hospital prior to acquiring the results of the western blot IgM and IgG titres and then travelled out of state and could not be contacted for that period of time.

This case underscores that patients exposed to areas endemic for the spirochete Borrelia Burgdorferi should be highly suspected of developing Lyme disease even if the only manifestation is cardiac. Isolated Lyme carditis occurs at an incidence of up to $10 \%$. Palpitations, conduction abnormalities, myocarditis, cardiac dysfunction and pericarditis may occur. ${ }^{1-3}$

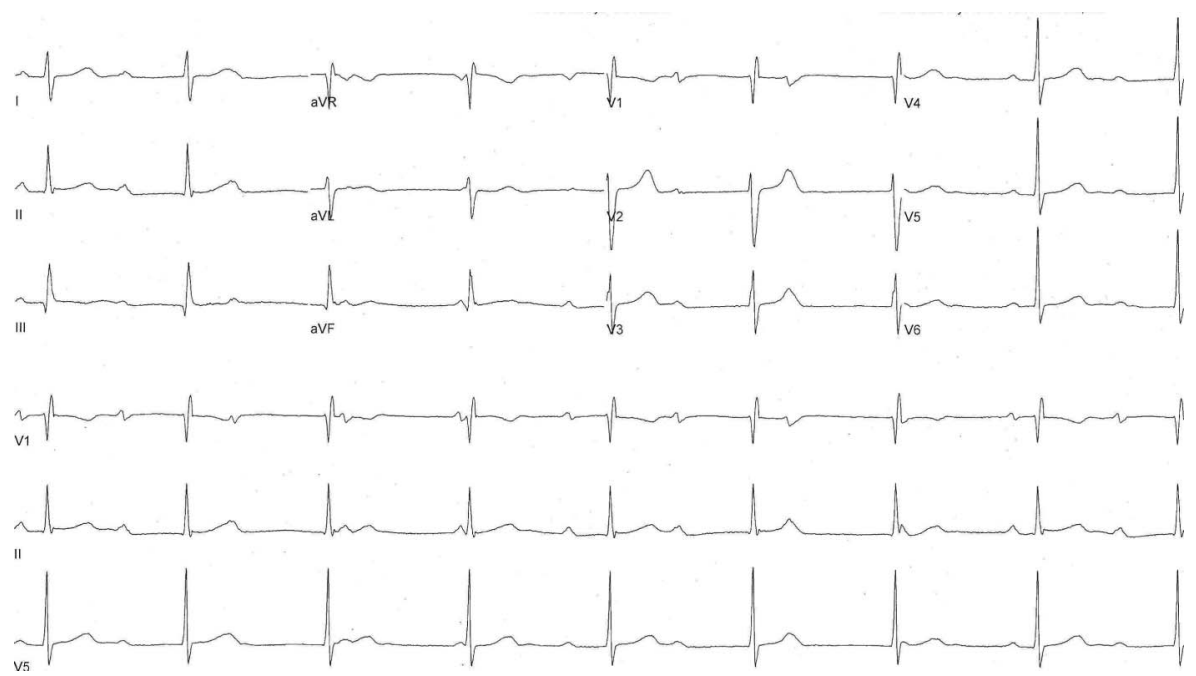

Figure 1 ECG of the patient. 


\section{BMJ Case Reports}

\section{Learning points}

- This case highlights the need to have a high index of suspicion for contraction of Lyme disease when patients develop febrile illness after travel to areas endemic with Borrelia Burgdorferi.

- Isolated cardiac manifestations of Lyme disease are uncommon but do happen.

- Awareness of travel-related diseases is necessary and important.

- Aggressive treatment with intravenous ceftriaxone or benzyl penicillin of patients who have developed complete heart block and are suspected of having Lyme disease may prevent the need for placement of a permanent pacemaker.

- It is helpful to obtain expert advice regarding travel-related diseases, required testing for those diseases and interpretation of serological test results.

\section{Competing interests None.}

Patient consent Obtained.

\section{REFERENCES}

1. Koene R, Boulware DR, Kemperman M, et al. Acute heart failure from Lyme carditis. Circ Heart Fail 2012;5:e24-6.

2. Dolbec KWD, Higgins III GL, Saucier JR. Lyme carditis with transient complete heart block. West J Emerg Med 2011;11:211-12.

3. Nalmas S, Nagarakanti R, Slim J, et al. Electrocardiographic changes in infectious diseases. Hospital Phys 2007;15-27.

Copyright 2012 BMJ Publishing Group. All rights reserved. For permission to reuse any of this content visit http://group.bmj.com/group/rights-licensing/permissions.

BMJ Case Report Fellows may re-use this article for personal use and teaching without any further permission.

Please cite this article as follows (you will need to access the article online to obtain the date of publication).

Lutwak N, Dill C. 53-Year-old man with fever, malaise and dyspnoea. BMJ Case Reports 2012;10.1136/bcr-2012-007248, Published XXX

Become a Fellow of BMJ Case Reports today and you can:

- Submit as many cases as you like

- Enjoy fast sympathetic peer review and rapid publication of accepted articles

- Access all the published articles

- Re-use any of the published material for personal use and teaching without further permission

For information on Institutional Fellowships contact consortiasales@bmjgroup.com

Visit casereports.bmj.com for more articles like this and to become a Fellow 